\title{
Polyfluorene/Carbon Nanocomposite for Electrochemical Capacitors
}

\author{
Kenji Machida, Shunzo Suematsu, and Kenji Tamamitsu* \\ Research Center, Nippon Chemi-Con Corporation (363, Arakawa, Takahagi-shi, Ibaraki 318-8505, Japan) \\ Received January 31, 2007 ; Accepted June 6, 2007
}

\begin{abstract}
A nanocomposite material based on polyfluorene (PF) loaded with a carbon black, namely Ketjen Black (KB), was investigated electrochemically as a cathode material for high-energy electrochemical capacitors. The nanocomposite was prepared by a chemical oxidation of fluorene monomer dissolved in the KB suspension. From TEM observation, thin PF films with 5-15 nm in thickness were loaded onto the surface of the aggregated KB particles. The nanocomposite based capacitor electrode exhibited high specific capacitance of $160 \mathrm{~F} \mathrm{~g}^{-1}\left(260 \mathrm{~F} \mathrm{~g}^{-1}\right.$ per PF mass) in an electrolyte of $1 \mathrm{M}$ tetraethylammonium tetrafluoroborate/propylene carbonate. More importantly, the charge was found to be stored at high potential ranged from 0.4 to $1.0 \mathrm{~V}$ vs. Ag/ $\mathrm{Ag}^{+}$, which is higher than the redox potentials for conventional conducting polymers.
\end{abstract}

Key Words : Electrochemical Capacitor, Polyfluorene, Nanocomposite, Ketjen Black

\section{Introduction}

Conducting polymers have been studied widely as electrode material in energy devices and more particularly in electrochemical capacitors. ${ }^{1-13)}$ Charge storage of the conducting polymer based electrochemical capacitors is based on redox reaction of $\pi$-conjugated system (pdoping or n-doping) in the conducting polymer, while charge storage of conventional electric double layer capacitors is double layer charging/discharging at the surface of activated carbon electrode. Rudge et $a l .^{1)}$ reported electrochemical capacitors based on only one type of conducting polymer, such as polyaniline, that can be reversibly p-doped (Type I capacitors, cell voltage: $1 \mathrm{~V})$. Also, capacitors based on $\mathrm{p}$ - and n-dopable polymer such as polythiophene derivatives have been studied (Type III capacitors, cell voltage: $\sim 3 \mathrm{~V}$ ). ${ }^{1,2,5)}$

For higher energy density, hybrid-type electrochemical capacitors (HEC) have been proposed in recent years. ${ }^{6.9-12)}$ For instance, Mastragostino et al. ${ }^{9)}$ reported a high energy HEC $\left(\sim 24 \mathrm{Wh} \mathrm{kg}^{-1}\right.$, cell voltage: $\left.\sim 3.6 \mathrm{~V}\right)$ composed of an activated carbon as the anode and poly(3-methylthiophene) [p3MeT] as the cathode. The high energy is attributed to high capacitance $\left(100 \sim 230 \mathrm{~F} \mathrm{~g}^{-1}\right)$ and high redox potential $\left(\sim 0.7 \mathrm{~V}\right.$ vs. $\left.\mathrm{Ag} / \mathrm{Ag}^{+}\right)$of the p3MeT cathode. To obtain more high redox potential, other polythiophene derivatives $\left(\sim 0.9 \mathrm{~V}\right.$ vs. $\left.\mathrm{Ag} / \mathrm{Ag}^{+}\right)$were investigated. $6,10,11)$

The authors have been studying a polyfluorene (PF, Fig. 1) as a cathode material for high energy HEC. The film shows reversible redox reaction at higher redox potential $\left(\sim 1.2 \mathrm{~V} \text { vs. } \mathrm{Ag} / \mathrm{Ag}^{+}\right)^{14,15)}$ compared with other polymers mentioned above. A first report for electrochemical properties of the PF material for electrochemical capacitors was published in 2006. The report revealed that the pure PF material was found to show low electrochemical capacity because of low electronic conductivity of the bulk PF. ${ }^{13)}$ For enhancement of electrochemical activity of the PF, addition of electroconduc-

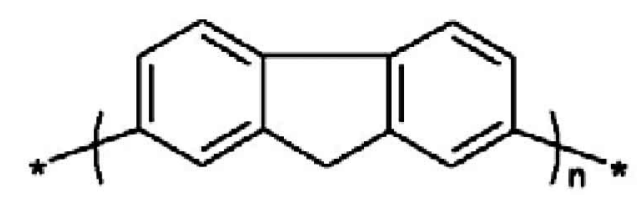

Fig. 1 Structure of polyfluorene (PF).

tive material with the $\mathrm{PF}$ is required.

In this study, a nanocomposite material based on $\mathrm{PF}$ loaded with a nanocarbon substrate, namely Ketjen Black (KB) having high specific surface area $\left(800 \mathrm{~m}^{2} \mathrm{~g}^{-1}\right)$, high electronic conductivity $\left(\sim 10^{\circ} \mathrm{S} \mathrm{cm}^{-1}\right)$ and low cost, was prepared and was investigated for its electrochemical capacitor properties.

\section{Experimental}

The polyfluorene/Ketjen Black nanocomposite ( $\mathrm{PF} / \mathrm{KB}$ nanocomposite) powder was prepared by following procedures. Firstly, KB powder (Ketjen Black Interational Co.) was crushed mechanically by use of mixer (generalpurpose) for 1 minute. Then, obtained KB powder was dispersed into $10 \mathrm{mmol}$ of fluorene monomer $(98 \%$, Wako Chemicals) dissolved in chloroform under ultrasonication for 30 minutes. The KB amounts $(W)$ were $1.0,3.0$, $5.0,10$ and $20 \mathrm{wt} \%$ for fluorene mass. Into the suspension, $10 \mathrm{mmol}$ of iron trichloride (98\%, Aldrich) as an oxidizing agent was added. After stirring for $72 \mathrm{~h}$, the solution was filtered with a Teflon filter (200 $\mathrm{nm}$ of pore size, Millipore). The obtained deposit was washed with chloroform, methanol, and distilled water to remove inactiveoligomer species, monomers, iron ions and chlorides. Thereafter, it was dried under reduced pressure at 60 degree $\mathrm{C}$ for 6 hours to obtain a black colored nanocomposite powder. Actual specific content of $\mathrm{KB}\left(W_{\mathrm{re}}\right)$ in the nanocomposite powder was calculated by following equation; 


$$
W_{\mathrm{re}}=M_{\mathrm{KB}} / Y_{\mathrm{com}}
$$

where $M_{\mathrm{KB}}$ and $Y_{\text {com }}$ are the added KB mass at preparation and the nanocomposite powder mass, respectively. Chemical structure and nanostructure of the nanocomposite powder were characterized by FTIR spectroscopy and TEM observation, respectively.

The $\mathrm{PF} / \mathrm{KB}$ nanocomposite capacitor electrode was fabricated by mixing $85 \mathrm{wt} \% \mathrm{PF} / \mathrm{KB}$ nanocomposite powder, $10 \mathrm{wt} \%$ carboxymethylcellulose and $5 \mathrm{wt} \%$ elastomer binder. The mixture was coated onto an $\mathrm{Al}$ current collector. Thickness and geometric area of the capacitor electrode were $20 \mu \mathrm{m}$ and $1 \mathrm{~cm}^{2}$, with single electrode mass loading in the range from 0.5 to $0.6 \mathrm{mg}$ (electrode density: $0.25-0.30 \mathrm{~g} \mathrm{~cm}^{-3}$ ). Electrochemical characteristics of the capacitor electrode were evaluated by cyclic voltammetry (HZ-3000 system, Hokuto Denko). A three-electrode cell was used, with the $\mathrm{PF} / \mathrm{KB}$ electrode as the working electrode, an activated carbon sheet (commercially purchased, $6 \mathrm{~cm}^{2}, 150 \mu \mathrm{m}$ in thickness) as the counter electrode, and $\mathrm{Ag} / \mathrm{Ag}^{+}$electrode as the reference electrode (consisting of $\mathrm{Ag}$ wire in a solution of $10^{-2} \mathrm{M} \mathrm{AgNO}_{3}$ in propylene carbonate). The potential of this reference electrode was $+0.30 \mathrm{~V}$ vs. $\mathrm{Ag} / \mathrm{Ag}^{+}$reference electrode using acetonitrile solution with same electrolyte salt. In this study, the potential was expressed as vs. $\mathrm{Ag} / \mathrm{Ag}^{+}$using the acetonitrile solution for comparison with other reports. The counter electrode and the working electrode were sandwiched by two glass plates through a cellulose separator $(60 \mu \mathrm{m}$ in thickness). As an electrolyte, $1 \mathrm{M}$ tetraethylammonium tetrafluoroborate dissolved in propylene carbonate $\left(\mathrm{TEABF}_{4} / \mathrm{PC}\right)$ was used for the electrochemical measurements. The cell assembles and the electrochemical measurements were carried out in argon atmosphere.

\section{Results and Discussion}

From FTIR spectra, the nanocomposite powder sam-

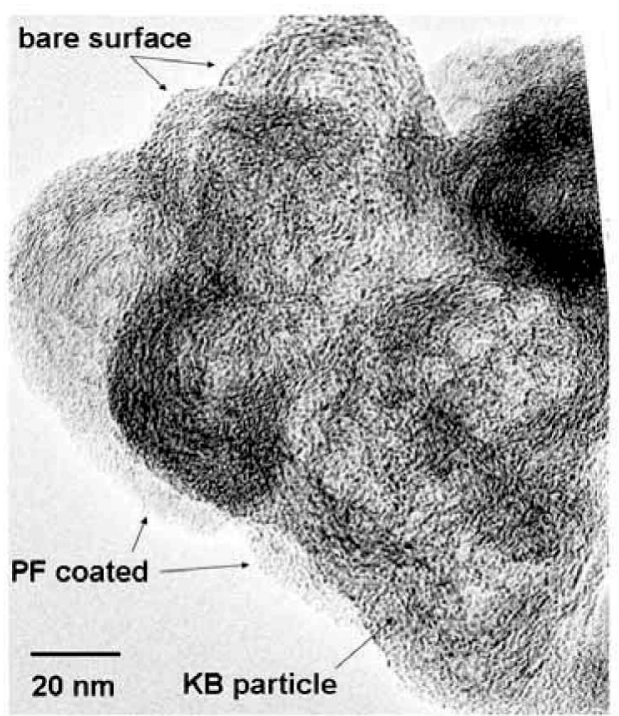

Fig. 2 TEM image obtained for $\mathrm{PF} / \mathrm{KB}$ nanocomposite powder $\left(W_{\text {re }}=45 \mathrm{wt} \%\right)$.
Table 1 Specific contents of $\mathrm{KB}\left(W_{\mathrm{re}}\right)$ in $\mathrm{PF} / \mathrm{KB}$ nanocomposite powder contrasted with adding $\mathrm{KB}$ amount $(W)$ at nanocomposite preparation.

\begin{tabular}{cc}
\hline$W / \mathrm{wt} \%$ & $W_{\mathrm{re}} / \mathrm{wt} \%$ \\
\hline 1.0 & 7.9 \\
3.0 & 16 \\
5.0 & 40 \\
10 & 45 \\
20 & 68
\end{tabular}

ples were found to consist of electroactive PF with main bonding manner of 2,7 position like a structure in Fig. 1, corresponding to the peaks at $820,760,730 \mathrm{~cm}^{-1}$ assigned to 1,2,4-tri-substituted aromatic ring, ${ }^{16)}$ as well as the pure PF powder. Specific contents of $\mathrm{KB}\left(W_{\mathrm{re}}\right)$ in the $\mathrm{PF} / \mathrm{KB}$ nanocomposite powders were summarized in Table 1 . The $W_{\text {re }}$ values were significantly different from the added $\mathrm{KB}$ amounts $(W)$ at the nanocomposite preparation. This indicates that polymerization efficiency (obtained PF mass /added monomer mass) of the PF in the nanocomposite were very low $(8 \sim 12 \%)$ of all the preparations due to dissolution of soluble oligomer species by the chloroform washing.

Figure 2 shows TEM image of the nanocomposite powder $\left(W_{\mathrm{re}}=45 \mathrm{wt} \%\right.$ sample). The certain species perceived as PF films $(5-15 \mathrm{~nm})$ formed onto the aggregated $\mathrm{KB}$ particles were observed, and also bare $\mathrm{KB}$ surfaces were confirmed. At the low $W_{\text {re }}$ samples (or high $\mathrm{PF}$ content samples), the PF species were increasingly observed in the respective SEM images. In the case of sample of $W_{\text {re }}=7.9 \mathrm{wt} \%$, the bulk PF fragments (micrometer size) were observed, leading to low specific capacitance.

Cyclic voltammogram recorded at a scan rate of $5 \mathrm{mV}$ $\mathrm{s}^{-1}$ in $1 \mathrm{M} \mathrm{TEABF} / \mathrm{PC}$ for the $\mathrm{PF} / \mathrm{KB}$ nanocomposite electrode ( $W_{\text {re }}=40 \mathrm{wt} \%$ sample) is depicted in Fig. 3(a) and clearly indicates that the electrochemical redox reaction (p-doping/dedoping) occurred reversibly compared with the voltammogram for pure $\mathrm{KB}$ electrode (Fig. 3(b)). The redox potential is ranged from +0.4 to $+1.0 \mathrm{~V}$ vs. $\mathrm{Ag} / \mathrm{Ag}^{+}$, which is higher than the conventional polymers such as p3MeT $\left(\sim+0.7 \mathrm{~V} \text { vs. } \mathrm{Ag} / \mathrm{Ag}^{+}\right)^{9)}$ or

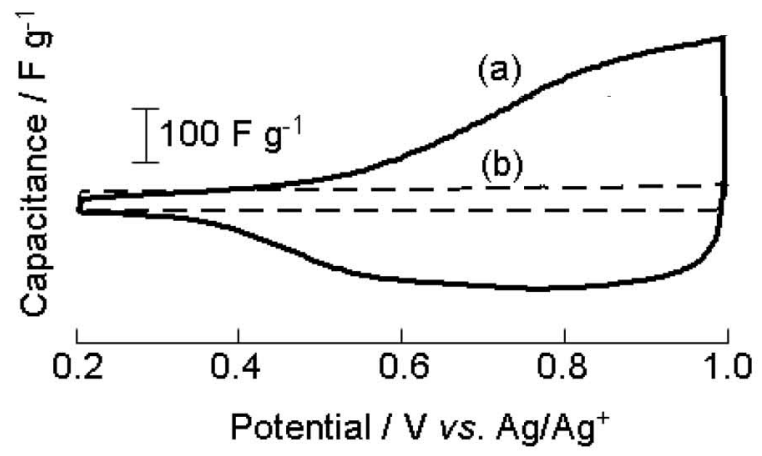

Fig. 3 Cyclic voltammograms obtained for (a) $\mathrm{PF} / \mathrm{KB}$ nanocomposite electrode $\left(W_{\mathrm{re}}=40 \mathrm{wt} \%\right.$ ), (b) pure $\mathrm{KB}$ electrode as a blank. 


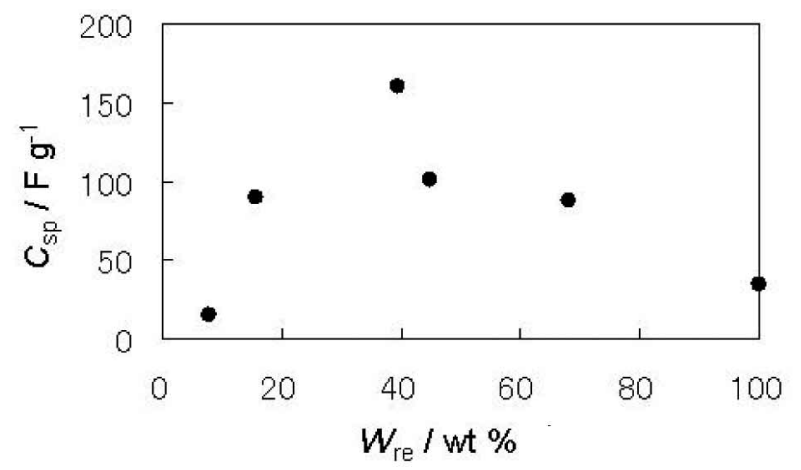

Fig. 4 Specific capacitance $\left(C_{\mathrm{sp}}\right)$ obtained for $\mathrm{PF} / \mathrm{KB}$ nanocomposite electrodes as a function of specific contents of $\mathrm{KB}\left(W_{\mathrm{re}}\right)$ in $\mathrm{PF} / \mathrm{KB}$ nanocomposites.

other polythiophene derivatives $(\sim+0.9 \mathrm{~V}$ vs. $\left.\mathrm{Ag} / \mathrm{Ag}^{+}\right)^{6,10,11)}$ studied as electrochemical capacitors previously. Specific capacitance $\left(C_{\mathrm{sp}}\right)$ obtained for the $\mathrm{PF} / \mathrm{KB}$ nanocomposite electrodes as a function of the $W_{\text {re }}$ is shown in Fig. 4. It is revealed the $C_{\mathrm{sp}}$ value strongly depends on the $W_{\text {re, }}$ and the maximum value of $160 \mathrm{~F} \mathrm{~g}^{-1}$ is obtained for the sample of $W_{\text {re }}=40 \mathrm{wt} \%$. Figure 5 shows specific capacitance per PF mass $\left(C_{\mathrm{PF}}\right)$ as a function of $W_{\text {re. }}$ The maximum $C_{\mathrm{PF}}$ is $c a .260 \mathrm{~F} \mathrm{~g}^{-1}\left(32 \mathrm{mAh} \mathrm{g}^{-1}\right)$, which is $40 \%$ of charge utilization (theoretical value is $80 \mathrm{mAh}^{-1}$ assuming to 0.5 of maximum doping level). The high $C_{\mathrm{PF}}$ is probably attributed to optimized electron pathway and ion transfer in the $\mathrm{PF} / \mathrm{KB}$ nanocomposite electrode. This will be supported by investigating some additional experiments especially in electrochemical impedance spectroscopy.

\section{Conclusion}

A nanocomposite based on PF loaded with $\mathrm{KB}$ was prepared and was investigated for electrochemical capacitor properties. The nanocomposite electrode was found to be exhibited unprecedented high redox potential, and showed high specific capacitance of $160 \mathrm{~F} \mathrm{~g}^{-1}$ obtained from the nanocomposite sample composed of 40 $\mathrm{wt} \%$ of KB. These electrochemical characteristics of the $\mathrm{PF} / \mathrm{KB}$ nanocomposite are promising for the use in highenergy electrochemical capacitors.

\section{Acknowledgement}

This work is partial supported by the New Energy and Industrial Technology Development Organization (NEDO) of "Carbon Nanotube Capacitor Project", Japan.

\section{References}

1) A. Rudge, I. Raistrick, S. Gottesfeld, and J. P. Ferraris,

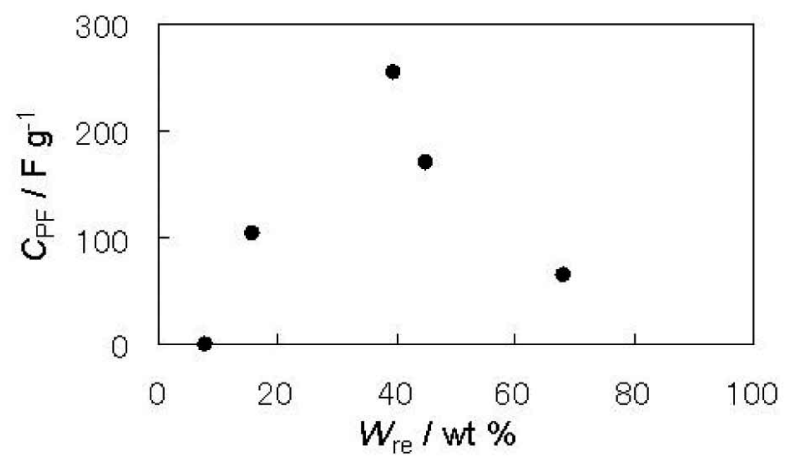

Fig. 5 Specific capacitance per PF mass $\left(C_{\mathrm{sp}}\right)$ obtained for $\mathrm{PF} / \mathrm{KB}$ nanocomposite electrodes as a function of specific contents of $\mathrm{KB}\left(W_{\mathrm{re}}\right)$ in $\mathrm{PF} / \mathrm{KB}$ nanocomposites.

Electrochim. Acta, 39, 273 (1994).

2) J. P. Ferraris, M. M. Eisssa, I. D. Brotherson, and D. C. Loveday, Chem. Mater., 10, 3528 (1998).

3) D. Belanger, X. Ren, J. Davey, F. Uribe, and S. Gottesfeld, J. Electrochem. Soc., 147, 2923 (2000).

4) M. Mastragostino, C. Arbizzani, R. Paraventi, and A. Zanelli, J. Electrochem. Soc., 147, 407 (2000).

5) K. Naoi, S. Suematsu, and A. Manago, J. Electrochem. Soc., 147, 420 (2000).

6) A. Laforgue, P. Simon, J. F. Fauvarque, J. F. Sarrau, and P. Lailler, J. Electrochem. Soc., 148, A1130 (2001).

7) F. Fusalba, P. Gouerec, D. Villers, and D. Belanger, J. Electrochem. Soc., 148, A1 (2001).

8) J. D. Smith, C. K. Webber, N. Anderson, A. P. Chafin, K. Zong, and J. R. Reynolds, J. Electrochem. Soc., 149, A973 (2002).

9) A. Laforgue, P. Simon, J. F. Fauvarque, M. Mastragostino, F. Soavi, J. F. Sarrau, P. Lailler, M. Conte, E. Rossi, and S. Saguatti, J. Electrochem. Soc., 150, A645 (2003).

10) D. Villers, D. Jobin, C. Soucy, D. Cossement, R. Chahine, L. Breau, and D. Belanger, J. Electrochem. Soc., 150, A747 (2003).

11) A. Balducci, W. A. Henderson, M. Mastragostino, S. Passerini, P. Simon, and F. Soavi, Electrochim. Acta, 50 (2005).

12) K. Machida, Y. Nakagawa, N. Ogihara, and K. Naoi, Electrochemistry, 73, 1035 (2005) [in Japanese].

13) S. Suematsu, TANSO, 223, 165 (2006) [in Japanese].

14) J. R-Berthelot and J. Simonet, New J. Chem., 10, 169 (1986).

15) J. Xu, Z. Wei, Y. Du, W. Zhou, and S. Pu, Electrochim. Acta, 51, 4771 (2006).

16) J. Xu, Y. Zhang, J. Hou, Z. Wei, S. Pu, J. Zhao, and Y. Du, Eur. Polym. J., 42, 1154 (2006). 